\title{
Influence of low-level laser application on root resorption and pulp alterations during tooth movement
}

\author{
Mariana Marquezan*, Lívia Kelly Ferraz Nunes**, Amanda Osório \\ Ayres de Freitas*, Marcelo Sampaio Narciso***, Matilde da Cunha \\ Gonçalves Nojima ${ }^{\star * \star *}$, Mônica Tirre de Souza Araújo ${ }^{\star \star * *}$, Ana Maria \\ Bolognese $^{\star \star \star \star \star *}$, Antônio Carlos de Oliveira Ruellas ${ }^{\star \star \star \star \star *}$
}

\begin{abstract}
The purpose of this study was to determine the effects of low-level laser (LLL) irradiation on root resorption and dental pulp during experimental tooth movement. Five groups were delineated: a control group without orthodontic force or LLL application, 2 other controls in which orthodontic force was applied for 2 and 7 days respectively, and two experimental groups with orthodontic force and LLL application for 2 and 7 days respectively. To induce experimental tooth movement in rats, orthodontic force of $40 \mathrm{cN}$ was applied to the left first molars. In irradiated groups, Ga-Al-As diode laser (830 nm) was applied on 3 areas around the experimental maxillary molar: mesial, buccal and palatal. Two microscopic analyses were performed with HE staining: a quantitative for root resorption and a qualitative for pulp tissue reactions. Quantitative analysis showed that root resorptions were evident on day 7 of tooth movement. The irradiated group presented twice the amount of root resorption than the orthodontic control group, but this difference was not verified statistically ( $P=0.073)$. The qualitative pulp evaluation showed no significant alterations when orthodontic force or LLL were applied. Root resorption was verified when LLL was applied and no undesired effects on pulp tissue were observed.

Descriptors: Laser Therapy, Low-Level; Tooth Movement; Root Resorption; Dental Pulp.
\end{abstract}

\footnotetext{
* Doutoranda em Ortondentia na Universidade Federal do Rio de Janeiro (UFRJ), Rio de Janeiro, RJ, Brasil.

** Especialização em andamento na Universidade do Estado do Rio de Janeiro (UERJ), Rio de Janeiro, RJ, Brasil.

*** Mestre em Ciências Morfológicas pela Universidade Federal do Rio de Janeiro (UFRJ), Rio de Janeiro, RJ, Brasil.

${ }^{* * * *}$ Doutora em Odontologia pela Universidade Federal do Rio de Janeiro (UFRJ), Rio de Janeiro, RJ, Brasil.

***** Pós-Doutorado pela Northwestern University, Illinois, Estados Unidos.

****** Pós Doutorado pelo Instituto Militar de Enegenharia (IME), Rio de Janeiro, RJ, Brasil.
} 


\section{Influência da aplicação de laser de baixa potência sobre a reabsorção radicular e alterações da polpa durante o movimento dentário}

Resumo: 0 objetivo deste estudo foi determinar os efeitos do laser de baixa potência (LBP) na reabsorção radicular e polpa dentária durante a movimentação dentária experimental. Cinco grupos foram delineados: um grupo controle sem força ortodôntica ou aplicação LBP, dois grupos controles em que a força ortodôntica foi aplicada durante 2 e 7 dias respectivamente, e dois grupos experimentais com aplicação de força ortodôntica e de LBP durante 2 e 7 dias respectivamente. Para induzir a movimentação dentária experimental em ratos, $40 \mathrm{cN}$ foram aplicados aos primeiros molares esquerdos. Nos grupos irradiados, laser de diodo (Ga-Al-As $830 \mathrm{~nm}$ ) foi aplicado em 3 áreas em torno do molar superior experimental: mesial, vestibular e palatina. Duas análises microscópicas foram realizadas com coloração $\mathrm{HE}$ : uma quantitativa para avaliação da reabsorção radicular e outra qualitativa para avaliação das reações do tecido pulpar. A análise quantitativa mostrou que reabsorções radiculares foram evidentes no dia 7 de movimentação dentária. 0 grupo irradiado apresentou o dobro da quantidade de reabsorção radicular do que o grupo controle com movimentação dentária, mas essa diferença não foi verificada estatisticamente $(P=0,073)$. A avaliação qualitativa da polpa não apresentou alterações significativas quando a força ortodôntica ou LBP foram aplicados. Reabsorção radicular foi verificada quando LBP foi aplicado, entretanto, não foram verificados efeitos indesejáveis sobre o tecido pulpar.

Descritores: Terapia a Laser de Baixa Intensidade; Movimentação Dentária; Reabsorção da Raiz; Polpa Dentária. 


\section{Introduction}

Low-level laser (LLL) has been used in Orthodontics to relieve the pain associated with tooth movement ${ }^{1,2}$, accelerate bone regeneration during rapid maxillary expansion ${ }^{3}$ and to hasten orthodontic tooth movement ${ }^{4,5,6}$.

Shorter orthodontic treatments could mean more comfort to the patient, a lower risk of plaque accumulation and its consequences, and a lower risk of root resorption ${ }^{5}$ since long periods of treatment are associated with higher resorptive activity on the root surface ${ }^{7,8}$. Although shorter treatments can reduce the risk of root resorption, the use of chemical or physical agents to hasten tooth movement can cause the opposite effect: higher root resorption, as observed during protaglandins application ${ }^{9}$. Some studies using LLL to accelerate tooth movement found higher movement rates ${ }^{4,5,6}$ with an increased number of osteoclasts being observed in the periodontal ligament in animals ${ }^{4,5,10}$. However, the effects on root tissue were not examined.

The pulp-dentinal complex can also undergo alterations during tooth movement. These might range from vascular alterations to necrosis, but there is no agreement in the literature as regards the consequences of orthodontic movement in pulp viability ${ }^{11}$. When $L L L 18 \mathrm{~J} / \mathrm{cm}^{2}$ fluence applications were performed during tooth movement, no harmful effect on pulp tissue was found ${ }^{12}$. However, higher fluence must be tested because the best results for hastening tooth movement in rats were found when using $6000 \mathrm{~J} / \mathrm{cm}^{24,5}$.

The purpose of this study was to determine the side effects of LLL irradiation on root and pulp tissues during experimental tooth movement in rats using a high fluence of $6000 \mathrm{~J} / \mathrm{cm}^{2}$.

\section{Methods}

Animals

This in vivo experimental study sample consisted of 30 12-week-old male Wistar rats with a mean weight of $250 \mathrm{~g}$. The rats were divided into 2 groups, Irradiated Group (IrG) and Control Group (CG), and then subdivided into 5 groups according to the presence of experimental tooth movement and euthanasia day (Table 1).

\begin{tabular}{ccccc} 
Table 1: Group division of animals according to orthodontic tooth movement and euthanasia day. & \\
\hline IrG(Irradiated Group) & Subgroup & Orthodontic movement & Euthanasia Day & Number of animals \\
\hline CG & CG0 & No & 0 & 6 \\
(Control Group) & CG2 & Yes & 2 & 6 \\
& CG7 & Yes & 7 & 6 \\
IrG & IrG2 & Yes & 2 & 6 \\
(Irradiated Group) & IrG7 & Yes & 7 & 6 \\
\hline
\end{tabular}

The rats were housed in cages inside a room with a 12-h light/dark cycle and provided

Rev. Saúde (Santa Maria), Santa Maria, v.39, n.1, p. 55-63, Jan./Jul.2013. with powdered food to avoid damage to the orthodontic appliances, and filtered water ad libitum. All procedures were carried out under general anesthesia using intraperitoneal 
injection of a mixed solution of ketamine hydrochloride $(1,33 \mathrm{ml} / \mathrm{Kg})$ and xylazine hydrochloride $(0,67 \mathrm{ml} / \mathrm{Kg})$. This protocol was reviewed and approved by the Ethics Commission on Animal Use in Scientific Research at the Heath Center of the Universidade Federal do Rio de Janeiro (number 038/2008).

\section{Experimental tooth movement}

The orthodontic appliance was composed of a nickel titanium closed coil spring (Dental Morelli Ltda, Sorocaba, São Paulo, Brazil) linked to the maxillary left first molar by a stainless steel ligature wire $(0,008$ " - Dental Morelli Ltda, Sorocaba, São Paulo, Brazil), stretched to achieve $40 \mathrm{cN}^{13,14,15}$ using a vertically suspended lead weight, and then tied to the maxillary incisors with a second ligature wire. Force was applied once and therefore dissipated over time. No activations were performed. Composite resin (Transbond XT, 3M Unitek, Monrovia, California, USA) was used to cover the incisors to ensure maximum retention of the ligature. Finally, the mandibular incisors were cut to avoid damage to the orthodontic appliance by trauma from occlusion.

\section{Laser Irradiation}

A continuous wave gallium-aluminum-arsenide (Ga-Al-As) diode laser (Thera Lase, DMC Equipamentos, São Carlos, São Paulo, Brazil) with a wavelength of $830 \mathrm{~nm}$, power output of $100 \mathrm{~mW}$ and spot area of nearly $0.003 \mathrm{~cm}^{2}$ was used in this research. The rats were exposed to a $6000 \mathrm{~J} / \mathrm{cm}^{2}$ fluence daily application ${ }^{4,6}$. Irradiation was performed for 3 minutes on each of the three selected points around the experimental maxillary molar (mesial, buccal and palatal), corresponding to a total energy of $54 \mathrm{~J}$ (Figure 1).

\section{Microscopical examination}

The animals were euthanatized by decapitation and maxillary bones were dissected. The left maxillary molars and their associated periodontium and supporting bone of each rat were fixed in $10 \%$ neutral buffered formalin, decalcified in Morse Solution and placed in paraffin blocks. Cross sections $5 \mu \mathrm{m}$ thick were obtained from the cervical third of the root, and were stained with hematoxylin-eosin (HE).

All of the five roots of the first molar (mesial, middle buccal, middle palatal, disto buccal, and disto palatal root) were evaluated quantitatively for root resorption and qualitatively for pulp alterations.

Root resorption was measured in percentage (\%) ${ }^{16}$. Digitized photomicrographs, obtained with a Nikon Eclipse E600 microscope, at 100X magnification, and a DS-U2 camera (Nikon Corporation, Tokyo, Japan), were evaluated using Image J software (National Institute of Mental Health, Bethesda, Maryland, USA). For each root, the largest perimeter was determined by drawing a line that matched the outer limit of the cementum. In the regions of resorption lacunae, the outline was implemented with a virtual line, simulating the original shape of the root before the action of cementoclasts. The pulp tissue was also circumscribed. With these tracings, it was possible to calculate the total area of the root (cementum and dentin excluding the pulp), and the percentage of its resorption (area of lacunae) in square

Saúde (Santa Maria), v.39, n.1, p. 55-63, 2013. Influence of low-level laser application on root resorption and pulp alterations during tooth movement micrometers $\left(\mu \mathrm{m}^{2}\right)^{16}$ (Figure 2). Three sections of each animal were analyzed and means were obtained for statistical treatment ${ }^{15,17}$. 
Pulp alterations were assessed under light microscopy (Nikon Eclipse E600), at 100X, 400X and 1000X magnification. Analysis was performed to identify and qualify the four regions of the pulp: odontoblastic layer, cell-free zone of Weil, cell rich zone and pulp core (Figure 3), according the description given by Santamaria $\mathrm{Jr}{ }^{18}$ and Abi-Ramia ${ }^{12}$.

\section{$\underline{\text { Statistical Analysis }}$}

Data evaluation was carried out using the Statistical Package for Social Sciences (version 18, SPSS Inc., Chicago, Illinois, USA) at a level of significance of $5 \%$. The reliability of measurements was tested by the Intraclass Correlation Coefficient (ICC=1). The evaluation of root resorption revealed that only two groups presented craters, so intergroup comparison for root resorption was carried out by independent Student's-t test. The Pearson Correlation test was performed to verify whether the root area was related to the amount of resorption.

\section{Results}

Evaluation of the sections demonstrated that there was no root resorption in Groups CG0, CG2 and IrG2. It was only verified after 7 days of tooth movement (CG7 and IrG7). Descriptive statistics and the $P$ value generated by the independent Student's-t test are presented in Table 2. Comparing the amount of resorption among roots of CG7 and IrG7, it was shown that the root most affected by resorption was the disto buccal root (DBR), followed by the middle buccal (MBR) and disto palatal roots (DLR). The fourth most affected root was the middle palatal (MLR), and the least affected was the mesial root (MR).

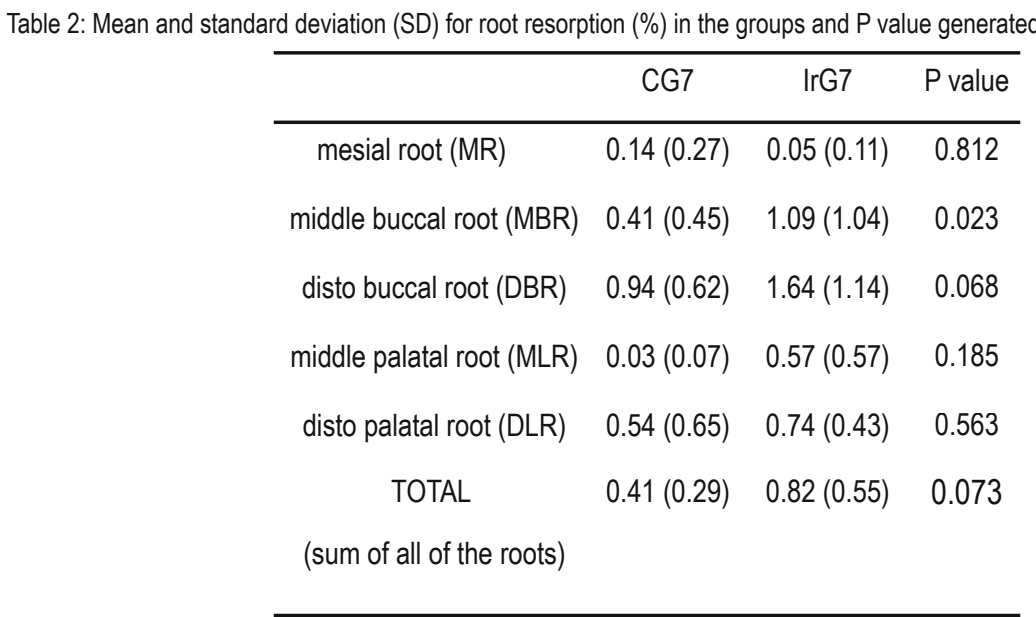

Correlation was observed between root area and root resorption area for the mesial root, $r=-1(P=0.000)$. The other roots presented no correlation between root area and resorption area.

The qualitative assessment of the pulp showed that the four zones evaluated odontoblastic layer, cell-free zone of Weil, cell-rich zone and pulp core - presented no significant alterations between the control and experimental groups. The odontoblastic layer was well organized and the predentin layer was similar in all the groups, presenting no increment of dentin during tooth movement or LLL application. The cell-free zone of Weil and

Rev. Saúde (Santa Maria), Santa Maria, v.39, n.1, p. 55-63, Jan./Jul.2013. Marquezan, M.; et al. 
cell-rich zone were visualized in all of the groups. The pulp core presented numerous congested vessels, especially filled with erythrocytes, as well as nerve bundles and homogeneously distributed fibroblasts. There were no fibroses, calcifications, inflammatory responses, decrease in vascularity or vessel constriction, or any decrease in cellularity during tooth movement and/or LLL irradiation.

\section{Discussion}

This article is the continuation of a previous study (Marquezan et al 2010) ${ }^{10}$. The first article evaluated the effects of laser application on periodontal ligament and in the quantity of tooth movement. This second article aims to discuss the side effects of LLL irradiation on pulp and root resorption.

Bone resorption and neoformation are desired periodontium responses to the force applied during the tooth movement. However, root resorption is an undesired side effect that occurs if the protective cementoblast layer is lost, exposing the root to clastic cells ${ }^{16}$. Orthodontic treatment is known to be the most common cause of root resorption. The factors associated with the onset and extent of resorption are not clearly understood, but they can be patient-related or treatment-related ${ }^{8}$.

Microscopically, this biological phenomenon is identified by the presence of Howship lacunae with or without clastic cells within them ${ }^{16}$. The results of this study showed that root resorption was verified only after 7 days of tooth movement, not being verified in 2 days. This finding is in agreement with Fracalossi ${ }^{16}$ and Nakano ${ }^{19}$, who found maximal expression of root resorption after 5 and 7 days of tooth movement, respectively. The comparison between the lased and non lased groups (IrG7 and CG7) revealed that LLL led to a twofold increase in the amount of root resorption, although there was no statistically significant difference. Evaluating the roots separately, the middle buccal root was the only one that presented statically significant difference. It has previously been verified that LLL increased the number of clastic cells during tooth movement ${ }^{4,6,10}$, but up to now, no side effects on root tissue had been verified. The activation of clastic cells was able to accelerate bone resorption and make the movement faster ${ }^{4,6}$, but the results of the present research demonstrated that the side effect was an increase in root resorption. The lack of statistical significance when evaluating the five roots together does not mean that LLL is safe when root resorption is considered. The result has clinical significance regardless the $P$ value found. Moreover, if the number of samples were a little larger, the $P$ value would probably decrease.

This study also showed that the size of the root was related to the amount of resorption. A perfect inverse correlation was found $(r=-1, P=0.000)$ for the mesial root. For this root, when its size increases, the resorptive effect decreases. In addition to the influence root size seems to have on its resorption, the position of the roots in the rat molar also influences the amount of resorption, as verified by Gonzales et al $(2008)^{20}$, who found larger resorption on distal roots.

Future studies should consider the evaluation of root resorption in different days after the

Saúde (Santa Maria), v.39, n.1, p. 55-63, 2013. Influence of low-level laser application on root resorption and pulp alterations during tooth movement beginning of ooth movement because this research evaluated only days 2 and 7 . The use of 3D analysis using micro-CT should also be considered so that a more accurate analysis of root craters can be performed. 
The results of qualitative pulp tissue analysis showed no significant alterations in experimental groups when compared with the control. The tooth movement and LLL irradiation were not harmful to the pulp tissue. Previous studys with regard to pulp reactions during tooth movement have suggested that pulp changes are transitory and reversible ${ }^{18,21}$ and when light forces are applied, the reactions occur to a minor extension ${ }^{22}$. When LLL was associated with tooth movement, slight changes have been previously observed in the pulp tissue ${ }^{12}$, but the authors concluded that these effects were not harmful, in agreement with this study.

Dental pulp is a soft connective tissue consisting of vessels, nerves and a mixed population of cells linked by an intercellular substance. The amount and characteristics of its constituents varies from the crown to the root apex. The four zones in which the pulp is arranged -the odontoblastic layer, cell-free zone of Weil, cell rich zone and pulp core - for example, are most easily visualized in the crown. According to Stenvik, Mjor ${ }^{23}$, pulp reactions to tooth movement decrease from the crown to the apex. Thus, it would be more interesting to evaluate the pulp tissue through longitudinal instead of transverse cross sections, although transverse sections allow visualization of the five roots.

Pulp tissue reactions to tooth movement are more pronounced in teeth with closed than in those with open apexes ${ }^{23}$. The rat molar, however, has a large apical foramen. The effects of tooth movement and LLL irradiation should perhaps be tested in another animal model to confirm this lack of harmful effect.

Although no undesired effect was observed in pulp during LLL application in rats submitted to tooth movement, root resorption was severe when laser was used. Further studies are necessary to test different irradiation dosages and prolonged tooth movement periods before adopting LLL in the orthodontic clinical routine, in order to assess its effects on tooth movement and its side effects.

\section{Conclusion}

Comparison of the lased and non lased groups submitted to tooth movement revealed that:

- Severe root resorption was verified when LLL was applied. However, no statistical significance was found;

- No undesired effect on pulp tissue was observed.

\section{Acknowledgments}

The authors would like to thank CAPES (Coordenação de Aperfeiçoamento Pessoal de nível superior) and FAPERJ (Fundação de Amparo à Pesquisa do Estado do Rio de Janeiro) for the financial support they provided, Dental Morelli Ltda., for donating the coil springs, and Bruno Marques for the assistance with the images. 


\section{Bibliographic References}

1. Shimizu N, Yamaguchi M, Goseki T, Shibata Y, Takiguchi H, Iwasawa T, Abiko Y. Inhibition of prostaglandin E2 and interleukin 1- $\beta$ production by low-power laser irradiation in stretched human periodontal ligament cells. J Dent Res. 1995 July;74(7):1382-1388.

2. Turhani $D$, Scheriau M, Benesch T, Jonke E, Bantleon HP. Pain relief by single low-level laser irradiation in orthodontic patients undergoing fixed appliance therapy. Am J Orthod. 2006 Sep; 130 (3): 371-376.

3. Saito S, Shimizu N. Stimulatory effects of lowpower laser irradiation on bone regeneration in midpalatal suture during expansion in the rat. Am J Orthod Dent Orthop. 1997 May;111(5):525-532.

4. Kawasaki K, Shimizu N. Effects of low-energy laser irradiation on bone remodeling during experimental tooth movement in rats. Lasers Surg Med. 2000; 26(3):282-291.

5. Cruz DR, Kohara EK, Ribeiro MS, Wetter NU. Effects of low-intensity laser therapy on the orthodontic movement velocity of human teeth: a preliminary study. Lasers Surg Med. 2004;35(2):117-120.

6. Fujita S, Yamaguchi M, Utsunomiya T, Yamamoto H, Kasai K. Low-energy laser stimulates tooth movement velocity via expression of RANK and RANKL. Orthod Craniofac. 2008 Aug;11(3):143-155.

7. Vardimon $A D$, Graber TM, Voss $L R$, Lenke J. Determinants controlling iatrogenic external root resorptions and repair during and after palatal expansion. Angle Orthod. 1991; 61(2):113-122.

8. Segal GR, Schiffman PH, Tuncay OC. Meta analysis of the treatment-related factors of external apical root resorption. Orthod Craniofac Res. 2004 May;7(2):71-78.

9. Seifi M, Shafeei HA, Daneshdoost S, Mir M. Effects of two types of low-level laser wave lengths (850 and $630 \mathrm{~nm}$ ) on the orthodontic tooth movements in rabbits. Lasers Med Sci. 2007 Nov;22(4):261-264.

10. Marquezan M, Bolognese AM, Araújo MT (2010) Effects of two low-intensity laser therapy protocols on experimental tooth movement. Photomed Laser Surg. 2010 Dec; 28(6):757-762.

11. Veberiene R, Smailiene D, Danielyte J, Toleikis A, Dagys A, Machiulskiene V. Effects of intrusive force on selected determinants of pulp vitality. Angle Orthod. 2009 Nov;79(6):1114-1118.

12. Abi-Ramia LB, Stuani AS, Stuani AS, Stuani MB, Mendes AM. Effects of low-level laser therapy and orthodontic tooth movement on dental pulps in rats. Angle Orthod. 2010 Jan; 80(1):116-122.

13. King GJ, Archer L, Zhou D. Later orthodontic appliance reactivation stimulates immediate appearance of osteoclasts and linear tooth movement. Am J Orthod Dentof Orthop. 1998 Dec;114(6):692-697.

14. Madan MS, Liu ZJ, Gu GM, King GJ. Effects of human relaxin on orthodontic tooth movement and periodontal ligaments in rats. Am J Orthod Dentof Orthop. 2007 Jan;131(1):8.e1-10.

15. Taweechaisupapong S, Srisuk N, Nimitpornsuko C, Vattraphoudes T, Rattanayatikul C, Godfrey K. Evening primrose oil effects on osteoclasts during tooth movement. Angle Orthod. 2005 May;75(3):356-361.

16. Fracalossi ACC, Santamaria Jr M, Consolaro MFMO, Consolaro A. Movimentação dentária experimental em murinos: períodos de observação e plano dos cortes microscópicos. R Dental Press Ortodon Ortop Facial. $2009 \mathrm{Jan} / \mathrm{Fev} ; 14(1): 143-157$.

17. Ren Y, Maltha JC, Kuijpers-Jagtman AM. The rat as a model for orthodontic tooth movement-a critical review and a proposed solution. Eur J Orthod. 2004 Oct;26(5):483-490.

18. Santamaria M Jr, Milagres D, lyomasa MM, Stuani MB, Ruellas AC. Initial pulp changes during orthodontic movement: histomorphological evaluation. Braz Dent J. 2007;18(1):34-39.

19. Nakano Y, Yamaguchi M, Fujjta S, Asano M, Saito K, Kasai K. Expressions of RANKL/RANK and M$\mathrm{CSF} / \mathrm{c}$-fms in root resorption lacunae in rat molar by heavy orthodontic force. Eur J Orthod. 2011 Aug;33(4):335-343. 
20. Gonzales C, Hotokezaka H, Yoshimatsu M, Yozgatian JH, Darendeliler MA, Yoshida N. Force magnitude and duration effects on amount of tooth movement and root resorption in the rat molar. Angle Orthod. 2008 May;78(3):502-509.

21. Stenvik A, Mjör IA. The effect of experimental tooth intrusion on pulp and dentine. Oral Surg Oral Med Oral Pathol. 1971 Oct;32(4):639-648.

22. Melsen B. Tissue reaction following application of extrusive and intrusive forces to teeth in adult monkeys. Am J Orthod. 1986 Jun; 89(9):469-475.

23. Stenvik A, Mjör IA. Pulp and dentine reactions to experimental tooth intrusion. A histologic study of the initial changes. Am J Orthod. 1970 Apr;57(4):370-385.

\section{Mariana Marquezan}

Endereço para correspondência - Avenida Professor Rodolpho Paulo Rocco, 325. Bairro Ilha do Fundão, Rio de Janeiro, CEP: 21941-617, RJ, Brasil.

E-mail: marianamarquezan@gmail.com

Currículo Lattes: http://lattes.cnpq.br/3239936595140832

Recebido em 25 de março de 2013.

Aprovado em 07 de maiol de 2013.

Rev. Saúde (Santa Maria), Santa Maria, v.39, n.1, p. 